\title{
Supplementary Table 6
}

\section{Comprehensive list of non-cysteine containing proteins exclusively quantified from biotin-free ${ }^{16} \mathrm{O} /{ }^{18} \mathrm{O}$-labeled peptide fraction $\mathrm{A}$.}

\begin{tabular}{|c|c|c|c|}
\hline Gene name & PAN $^{\mathbf{A}}$ & Protein description & $\mathbf{S C L}^{\mathrm{B}}$ \\
\hline ATPB_RAT & P10719 & ATP synthase beta chain, mitochondrial precursor (EC 3.6.3.14) & MPA \\
\hline Q6AXS4 & Q6AXS4 & Atp6ap2 protein (Renin/prorenin receptor) & MPI \\
\hline Q6P503 & Q6P503 & ATPase, $\mathrm{H}+$ transporting, lysosomal $34 \mathrm{kDa}$, V1 subunit D & MPA \\
\hline P70629 & P70629 & B-cell receptor associated protein 37 (Fragment) & MPA \\
\hline BASP_RAT & Q05175 & $\begin{array}{l}\text { Brain acid soluble protein } 1 \text { (BASP1 protein) (Neuronal axonal } \\
\text { membrane protein NAP-22) }\end{array}$ & MPA \\
\hline CYB5_RAT & P00173 & Cytochrome b5 & MPI \\
\hline COXH_RAT & P11950 & Cytochrome c oxidase polypeptide VIc-1 (EC 1.9.3.1) & MPI \\
\hline COXI_RAT & P11951 & Cytochrome c oxidase polypeptide VIc-2 (EC 1.9.3.1) & MPI \\
\hline COXJ_RAT & P35171 & $\begin{array}{l}\text { Cytochrome c oxidase polypeptide VIIa-liver/heart, mitochondrial } \\
\text { precursor (EC 1.9.3.1) (Cytochrome c oxidase subunit VIIa-L) }\end{array}$ & MPI \\
\hline COXO_RAT & P80432 & $\begin{array}{l}\text { Cytochrome c oxidase polypeptide VIIc, mitochondrial (EC 1.9.3.1) } \\
\text { (VIIIA) (Fragment) }\end{array}$ & MPA \\
\hline EMD_RAT & Q63190 & Emerin & MPI \\
\hline Q7M074 & Q7M074 & Fibronectin receptor alpha chain (Fragments) & MPA \\
\hline HO1_RAT & P06762 & Heme oxygenase 1 (EC 1.14.99.3) (HO-1) (HSP32) & MPI \\
\hline Q6P6S2 & Q6P6S2 & Hypothetical protein & MPI \\
\hline LEUK_RAT & P13838 & $\begin{array}{l}\text { Leukosialin precursor (Leucocyte sialoglycoprotein) (Sialophorin) } \\
\text { (CD43) (W3/13 antigen) (Fragment) }\end{array}$ & MPI \\
\hline Q6QI25 & Q6QI25 & LRRGT00183 & MPI \\
\hline
\end{tabular}




$\begin{array}{llll}\begin{array}{l}\text { Gene name } \\ \text { Q5U2V8 }\end{array} & \text { PAN } & \text { Protein description } & \text { SCL } \\ \text { Q5U2V8 } & \text { MGC94540 protein } & \text { MPI } \\ \text { SPC4_RAT } & \text { P42667 } & \begin{array}{l}\text { Microsomal signal peptidase 18 kDa subunit (EC 3.4.-.-) (SPase 18 } \\ \text { kDa subunit) (SPC18) (Endopeptidase SP18) }\end{array} & \text { MPI } \\ \text { SPC3_RAT } & \text { Q9WTR7 } & \begin{array}{l}\text { Microsomal signal peptidase 21 kDa subunit (EC 3.4.---) (SPase 21 } \\ \text { kDa subunit) (SPC21) }\end{array} & \text { MPI } \\ \text { Q6PDU7 } & \text { Q6PDU7 } & \text { Similar to CG6105-PA } & \text { MPI } \\ \text { STX3_RAT } & \text { Q08849 } & \text { Syntaxin-3 } & \text { MPI } \\ \text { SSRG_RAT } & \text { Q08013 } & \begin{array}{l}\text { Translocon-associated protein, gamma subunit (TRAP-gamma) } \\ \text { (Signal sequence receptor gamma subunit) (SSR-gamma) }\end{array} & \text { MPI } \\ \text { VATL_RAT } & \text { P63081 } & \text { Vacuolar ATP synthase 16 kDa proteolipid subunit (EC 3.6.3.14) } & \text { MPI } \\ \text { VATF_RAT } & \text { P50408 } & \begin{array}{l}\text { Vacuolar ATP synthase subunit F (EC 3.6.3.14) (V-ATPase F } \\ \text { subunit) (Vacuolar proton pump F subunit) (V-ATPase 14 kDa } \\ \text { subunit) } \\ \text { Vesicle transport through interaction with t-SNAREs homolog 1A } \\ \text { (Vesicle transport v-SNARE protein Vti1-like 2) (Vti1-rp2) }\end{array} & \text { MPI } \\ & \text { Q9JI51 } & & \text { MPA }\end{array}$

${ }^{\mathrm{A}}$ Protein Swiss-Prot/TrEMBL primary accession number; ${ }^{\mathrm{B}}$ Protein subcellular location: MPA $=$ membrane associated protein; MPI = integral membrane protein; 